\title{
Contract and Copyright Are Not at War: A Reply to "The Metamorphosis of Contract into Expand"
}

\author{
Joel Rothstein Wolfson $\dagger$
}

This Comment replies to David Nimmer, Elliot Brown, and Gary N. Frischling's Article that proposes state legislation declaring contracts unenforceable if they are "non-negotiable," to the extent they: I) license uncopyrightable information; or 2) "abrogate or restrict" fair use. Both prongs create unintended consequences that far outweigh benefits because: 1) uncopyrightable information is a fast growing and socially important industry; and 2) contractual restrictions on fair use serve important purposes (such as protecting privacy or guarding against piracy). This Comment observes that a test of "nonnegotiability" would prove unsustainable in practice, and that what the authors propose would not produce good law. This Comment suggests instead that we let courts use their existing powers to police oppressive terms or take the matter to Congress.

\section{INTRODUCTION}

In their Article The Metamorphosis of Contract into Expand, ${ }^{1}$ David Nimmer, Elliot Brown, and Gary N. Frischling take issue with Article 2B of the Uniform Commercial Code (U.C.C.). Specifically, the authors argue that Article $2 \mathrm{~B}$ subverts federal copyright policy by allowing information vendors to protect uncopyrightable material and to circumvent the fair use doctrine. As a remedy, they suggest annending Article $2 \mathrm{~B}$ to prevent "non-negotiable" contracts from imposing conditions that would achieve these results.

Copyright $\odot 1999$ California Law Review, Inc.

† Joel Rothstein Wolfson is an Associate General Counsel for The Nasdaq Stock Market, Inc. in Washington, D.C. He graduated with distinction in Mathematics from the University of Wisconsin, Madison and holds a J.D. from Cornell Law School.

1. David Nimmer et al., The Metamorphosis of Contract into Expand, 87 Calif. L. Rev. 17 (1999). 
This proposal (the Nimmer proposal) is essentially a repackaging of the McManis motion, a proposal that the bodies drafting Article 2B have already rejected. ${ }^{2}$ Despite the superficial appeal of the McManis motion-and now of the Nimmer proposal-this rejection is justified, because both proposals would create numerous harmful, if unintended, consequences.

This Comment has three Parts. Part I provides a brief legislative history of the McManis motion, which, like the Nimmer proposal, sought unsuccessfully to limit the scope of Article $2 \mathrm{~B}$, and then gives a brief overview of the Nimmer proposal. Part II addresses the practical difficulties that the Nimmer proposal would create for the information industries. Finally, Part III demonstrates how the authors' flawed proposal relies on an erroneous legal analysis of existing case law on contract and copyright and therefore is an unnecessary solution to a nonexistent problem.

\section{The Nimmer Proposal and the Rejected McManis Motion}

Article $2 \mathrm{~B}$ is a proposed addition to the U.C.C. that would govern licenses of information and software transactions. There are two cosponsors of the Article 2B effort, the American Law Institute (ALI) and the National Conference of Commissioners on Uniform State Laws (NCCUSL). The McManis motion is named for Professor Charles McManis of the Washington University School of Law, who introduced the following proposal at the 1997 Annual ALI Meeting:

I move that Section $2 \mathrm{~B}-308^{3}$ of the Discussion Draft of Uniform Commercial Code Article 2B (dated April 14, 1997) be amended by adding the following section (h):

2. The first half of the Article presents a thoughtful and interesting argument that the formalities of contract formation may not be necessary in simple mass-market software transactions. Unfortunately, that argument does not get the authors where they want to go-namely, the conclusion that "non-negotiable" contracts cannot protect uncopyrightable works or limit "fair use." So the authors shift their discussion to the Boucher Bill, which the authors champion, pulling the Article towards a justification of that bill, despite the authors' own arguments earlier in the piece. This Comment focuses on the second half of the Article, in which the authors advance their proposals to limit Article 2B's reach. For further discussion of the first half of the Article, see infra note 46. The Nimmer proposal, though closely modeled on the McManis motion and the Boucher Bill, was not officially presented for adoption; rather, it is shorthand for the authors' position.

3. At the time, 2B-308 was the section of Article $2 \mathrm{~B}$ that dealt with "mass-market transactions"- the concept analogous to the Nimmer proposal's "non-negotiable license." In the April 1997 Draft of Article 2B, a "mass-market transaction" was defined in $\S 2 \mathrm{~B}-102(26)$, in part, as:

[A] transaction in a retail market for information involving information directed to the general public as a whole under substantially the same terms for the same information, and involving an end user licensee that acquired the information in a transaetion under terms and in a quantity consistent with an ordinary transaction in the general retail distribution. 
(h) A term that is inconsistent with 17 U.S.C. Section 102(b) or with the limitations on exclusive rights contained in 17 U.S.C. Sections 107-112 and 117 cannot become part of a contract under this section. ${ }^{4}$

The discussion of the McManis motion at the 1997 Annual ALI meeting was relatively short, and it passed by a razor-thin margin of 86-84. Thereafter, both the information industries and the federal agencies that oversee thein mobilized to inform the other co-sponsor of the Article 2B, NCCUSL, of the effects of the motion. ${ }^{5}$ At its 1997 Annual Meeting, NCCUSL adopted the following motion:

In light of the significant concerns expressed by federal regulatory agencies, the major stock, commodity and mercantile exchanges and the software, publishing, entertainment and information industries, the Committee of the Whole believes that Article 2B should not address in its text the subject matter of the so-called McManis Motion, but should adopt a position of neutrality on the issues which are being actively debated at federal and international levels. This position of neutrality should be stated in the Official Comments. In light of the concerns articulated and this view, the Committee of the Whole respectfully suggests that ALI revisit the position expressed in a narrow vote at its 1997 Annual Meeting. ${ }^{6}$

Thus, NCCUSL not only rejected the McManis motion, but also took the unusual step of asking the ALI to reconsider its adoption of the McManis motion. The NCCUSL motion passed by a voice vote. Of the almost 400 delegates in the room, fewer than ten appeared to vote against the NCCUSL motion. Next, the Article 2B Drafting Committee

Id. [All versions of Article $2 \mathrm{~B}$ are available on the Internet. See National Conference of Commissioners on Uniform State Laws, Drafts of Uniform and Model Acts of Official Site (last modified Sept. 2, 1998) <http://www.law.upenn.edu/library/ulc/ulc.htm>. The Official Site offers the Article 2B drafts in several file formats, among which the pagination is inconsistent. In this Comment and throughout this issue of the California Law Review, page references are to the pages as they are numbered in the Acrobat PDF file format. Only the prefaces to the drafts are cited by page number; all other material is cited by section number. The draft of August 1, 1998, has no page numbers in its on-line version, and therefore the preface of that draft is cited without page references. $E d$.]

4. The motion and Professor McManis' supporting memorandum can be found at <http:// www.ali.org/ALI/McManis.htm> (visited Oct. 30, 1998).

5. Letters were submitted by the United States Securities and Exchange Commission, the United States Commodity Futures Trading Commission, the Information Industry Association (representing over 550 information providers), the Consolidated Tape Administration (representing a number of securities markets includimg the New York Stock Exchange, The Nasdaq Stock Market, Inc., and the American Stock Exchange), a separate letter from the Chair of The Nasdaq Stock Market, Inc., the New York Mercantile Exchange, the Options Price Reporting Authority, and the Chicago Mercantile Exchange along with the Chicago Board of Trade. Copies of some of these submissions can be found at <http://www.softwareindustry.org/issues/guide/nccusl.html > (visited Sept. 24, 1998).

6. The text of this motion can be found in a report about the meeting, at <http:// www.softwareindustry.org/issues/guide/nmtgrpt.html> (visited Sept. 24, 1998). 
took up the McManis motion. After an hours-long debate, it is fair to say that the Committee had little interest in the McManis inotion. In fact, no one on the Drafting Committee moved to adopt the McManis motion, or anything like it.

Finally, the McManis motion was broadened and reintroduced at the 1998 ALI Annual Meeting. It provided:

The current draft of proposed UCC Article $2 \mathrm{~B}$ has not reached an acceptable balance in its provisions concerning inass-market licenses (\$2B-208) and the relationship between Article $2 \mathrm{~B}$ and federal law ( $\$ 2 \mathrm{~B}-105$ ). Section $2 \mathrm{~B}-208$ reflects a persistent licensor bias that permeates the entire draft, substantially alters established principles of contract law, and creates a serious risk of conflict with, and eventual preemption in whole or in part by, federal copyright and/or patent law. Section 2B-105, while paying lip-service to the supremacy of federal law, does nothing to eliminate or reduce that risk of conflict, nor does it provide contracting parties or the courts with any meaningful guidance about how to avoid such conflicts. A fundainental change in approach is therefore needed to avoid the potential for conflict, not only between $\S 2$ B-208 and federal law, but also between U.S. law and various bodies of international and foreign law.

As the motion's supporting meinoranduin makes clear, the 1998 version of the McManis motion not only sought to reintroduce the wording of the original 1997 version, but also offered four other alternatives to accoinplish the same end. Professor McManis attributed two of these alternatives to papers presented at the April 1998 Berkeley conference that gave rise to this Symposium. ${ }^{8}$ After lengthy discussion, a voice vote was taken on the $1998 \mathrm{McMamis}$ motion. The vote was overwhelming in its rejection, so much so that the Chair did not even ask for a raising of hands to confirm the outcome (as the Chair did for some other motions made at the same session).

Now Nimmer and his co-authors have proposed their own amendment to Article $2 \mathrm{~B}$. The Nimmer proposal reads:

When a work is distributed to the public subject to nonnegotiable license terms, such terms shall not be enforceable [] to the extent that they-(1) linnit the reproduction, adaptation, distribution, performance, or display, by means of transmission or otherwise, of material that is uncopyrightable under section 102(b) [of the Copyright Act] or otherwise; or (2) abrogate or

7. The motion and Professor McManis' supporting memorandum can be found at <http:// www.ali.org/ALI/McManis2.htm> (last modified May 5, 1998) [hereinafter 1998 McManis Motion]. Detailed counter memoranda by Holly Towle, <http://www.ali.org/AL//towle2.htm> (last modified May 8, 1998), and this Comment's author, <http://www.ali.org/ALI/wolfson.htm>' (last modified May $13,1998)$, can also be found.

8. See 1998 McManis Motion, supra note 7, at 5-7. 
restrict the limitations on exclusive rights specified in sections 107 through 114 and sections 117 and 118 of [the Copyright Act]. ${ }^{9}$

The Nimmer proposal thus follows in the footsteps of the McManis motion, while broadening its scope and altering some of its details. The McManis inotion was cast as an amendment to section 308 of Article 2B and thus limited itself to "mass-inarket transactions," that is, licenses of products found in a retail market with quantities consistent with typical purchases in that marketplace. The Nimmer proposal extends to a far broader category of licenses, which could well include large procurements between sophisticated parties where the recipient of the standard form has reviewed the form, but because it appears acceptable, chooses not to negotiate the teruns. Likewise, the McManis motion limited itself to a "term that is inconsistent with 17 U.S.C. Section 102(b),"10 whereas the Nimmer proposal covers any limitation on "reproduction, adaptation, distribution, perfornance, or display, by means of transmission or otherwise," not just that which is inconsistent. The Nimmer proposal also extends its prohibitions to "nnaterial that is uncopyrightable under Section 102(b) or otherwise." 11 Finally, the McMamis motion declares unenforceable limitations inconsistent with "17 U.S.C. Sections 107112 and 117," whereas the Nimmer proposal extends to "sections 107 through 114 and sections 117 and 118."

The Nimmer proposal raises several interesting points. First, it declares unenforceable terms that purport to deal with "reproduction, adaptation, distribution, performance, or display, by means of transmission or otherwise" that the authors contend are (and I will refer to as) the "exclusive rights" of a copyright owner under section 102 of the Copyright Act when the license deals with "material that is uncopyrightable under section 102(b) [of the Copyright Act] or otherwise." Second, it declares unenforceable terms that purport to deal with exclusive rights where the terms "abrogate or restrict the limitations on exclusive rights specified in sections 107 through 114 and sections 117 and 118 of [the Copyright Act]." Third, it declares the above types of terms unenforceable only when they are "non-negotiable license terins."

9. Nimmer et al., supra note 1 , at 72 .

10. 17 U.S.C. $\$ 102(\mathrm{~b})$ provides:

In no case does copyright protection for an original work of authorship extend to any idea, procedure, process, system, method of operation, concept, principle, or discovery, regardless of the form in which it is described, explained, illustrated, or embodied in such Id. work.

11. Nimmer et al., supra note 1 , at 72 (emphasis added). 
II

The Harmful Unintended Consequences of THE NIMMER PROPOSAL

The Nimmer proposal would have several harmful unintended consequences for the information industries. Before turning to the flaws in the authors' legal analysis, then, I shall address four key areas where adoption of the Nimmer proposal would create undesirable outcomes: (1) denying protection to socially valuable but uncopyrightable information; (2) guaranteeing abuse of the "fair use" doctrine; (3) raising the ire of the United States' trading partners; and (4) creating an unworkable rule for "non-negotiable" contracts. Even if the current state of the law were as troublesome as the authors claim it is, that would still not justify legislation that would produce so many harmful results in the real world.

\section{A. The Growing Importance of Uncopyrightable Information}

An increasing proportion of the value of the United States economy depends on the creation and compilation of information "that is uncopyrightable under section 102(b) [of the Copyright Act] or otherwise," 12 for which contract is the chief, and sometimes the only, means of protection. Yet the authors would apparently deny such information any contractual protection from unauthorized copying.

A recent study highlights the importance of the information industries to the United States economy. Just in the last year, the American Electronics Association published Cybernation, a study of the importance of high-technology industries to the economy. ${ }^{13}$ The study contained statistics about the growth of the "information retrieval services" sector of the high-technology industry. While the category includes purveyors of both copyrighted and non-copyrighted information, there is no reason to believe that the uncopyrighted portion of the sector is growing any slower than the information sector as a whole. In tabular form, the study reported the following growth pattern:

\begin{tabular}{|l|l|l|}
\hline \multicolumn{1}{|c|}{ ITEM } & \multicolumn{1}{c|}{1996 FIGURES } & CHANGE 1990-1996 \\
\hline Employment & 69,793 & $+45.6 \%$ \\
\hline Establishments & 3,277 & $+134.7 \%$ \\
\hline Payroll & $\$ 3,180,480,997$ & $+69.8 \%$ \\
\hline Sales & $\$ 5,990,000,000$ & $+68.9 \%$ \\
\hline
\end{tabular}

12. Id.

13. See American Electronics Association, Cybernation (1998). In the interest of full disclosure, I note that this study was partially funded by The Nasdaq Stoek Market, Ine. 
These conclusions are similar to those published in the 1998 U.S. Industry and Trade Outlook. Discussing a segment of the information industry termed "electromic information services," that report stated:

This subsector grew at close to 9 percent on average between 1994 and 1996. Export revenues from this subsector were $\$ 1.3$ million im 1995, an increase of almost 15 percent. Exports increased at an average of 28 percent a year between 1992 and 1995, and strong export growth is expected to continue. ... Estimates, though sketchy, indicate that consumer on-line services had on the order of 9 to 11 million subscribers in 1995, a 70 to 100 percent increase over 1994. Growth of this inagnitude will probably continue through $2000 .^{14}$

Similarly, a 1998 study by Laura D'Andrea Tyson and Edward F. Sherry summarizes various statistics on what they term the "database industry": ${ }^{15}$

\begin{tabular}{|c|c|c|c|}
\hline INDUSTRY DESCRIPTION & $\begin{array}{l}\text { YEAR } \\
\text { SoURCE }\end{array}$ & SALES & OTHER DAta \\
\hline $\begin{array}{l}\text { 1. US publishing industry } \\
\text { and related services }\end{array}$ & 1996 & $\begin{array}{l}\$ 200 \\
\text { billion }\end{array}$ & \\
\hline $\begin{array}{l}\text { 2. Newspapers, books, } \\
\text { and magazines }\end{array}$ & 1996 & $\begin{array}{l}\$ 85 \\
\text { billion }\end{array}$ & \\
\hline $\begin{array}{l}\text { 3. Data processing and } \\
\text { network services, } 1993\end{array}$ & 1994 & $\begin{array}{l}\$ 46.4 \\
\text { billion }\end{array}$ & \\
\hline $\begin{array}{l}\text { 4. Business information } \\
\text { suppliers }\end{array}$ & 1996 & $\begin{array}{l}\$ 26 \\
\text { billion }\end{array}$ & \\
\hline $\begin{array}{l}\text { 5. Data processing and } \\
\text { preparation, SIC } 7374\end{array}$ & 1997 & $\begin{array}{l}\$ 21.4 \\
\text { billion }\end{array}$ & $\begin{array}{l}167 \text { companies, } \\
180,700 \text { employees }\end{array}$ \\
\hline $\begin{array}{l}\text { 6. Electronic information } \\
\text { industry }\end{array}$ & 1996 & $\begin{array}{l}\$ 15 \\
\text { billion }\end{array}$ & \\
\hline $\begin{array}{l}\text { 7. Database revenues of } \\
\text { business information, } \\
1994\end{array}$ & 1996 & $\begin{array}{l}\$ 13.8 \\
\text { billion }\end{array}$ & \\
\hline $\begin{array}{l}\text { 8. } 1993 \text { Electronic in- } \\
\text { formation services }\end{array}$ & 1994 & $\begin{array}{l}\$ 13.6 \\
\text { billion }\end{array}$ & \\
\hline $\begin{array}{l}\text { 9. } 1995 \text { Electronic deliv- } \\
\text { ery of business infor- } \\
\text { mation (primarily on- } \\
\text { line and CD-ROM) }\end{array}$ & 1996 & $\begin{array}{l}\$ 10.7 \\
\text { billion }\end{array}$ & \\
\hline
\end{tabular}

14. Def't OF Commerce, U.S. Industry \& TRADe OUtlooK ‘98 26-28 (1998).

15. Laura D'Andrea Tyson \& Edward F. Sherry, Statutory Protection for Databases: ECONOMIC aNd Public Policy Issues 9 (1998) <http://www, house.gov/judiciary/ 41118.htm> (visited Sept. 24, 1998). Reprinted with permission. 


\begin{tabular}{|c|c|c|l|}
\hline $\begin{array}{c}\text { 10. Information retrieval } \\
\text { services, SIC 7375 }\end{array}$ & 1997 & $\begin{array}{l}\$ 7.8 \\
\text { billion }\end{array}$ & $\begin{array}{l}345 \text { companies, } \\
60,800 \text { employees }\end{array}$ \\
\hline $\begin{array}{c}\text { 11. Commercial non- } \\
\text { physical research, SIC } \\
8732\end{array}$ & 1997 & $\begin{array}{l}\$ 4.5 \\
\text { billion }\end{array}$ & $\begin{array}{l}413 \text { companies, } \\
52,000 \text { employees }\end{array}$ \\
\hline
\end{tabular}

In addition to these studies, recent cases illustrate the principle that important information products are often not protected-or are only weakly protected-by copyright. A good start is ProCD v. Zeidenberg. ${ }^{16}$ There, ProCD had produced a CD-ROM of 95,000,000 residential and commercial telephone listings compiled from approximately 3,000 publicly available telephone books. ${ }^{17}$ As the Court of Appeals noted, ProCD spent over $\$ 10,000,000$ to compile the information from the directories onto its CD-ROM. ${ }^{18}$ Unquestionably, a CD-ROM of telephone directories is a socially useful product that costs millions of dollars to produce, verify, market, support, and update. Yet, copyright protection was completely unavailable to protect ProCD from a graduate student, Matthew Zeidenberg, who took the entire CD-ROM and posted it on the Internet in competition with ProCD. Needless to say, Zeidenberg incurred none of the costs of producing the $C D$, but used it to attract 20,000 hits per day on his World Wide Web site. ${ }^{19}$

Were it not for the ability of ProCD to protect its product contractually, ProCD would have had no cause of action against Zeidenberg, who would have been free to reap what he had not sown. Had the Nimmer proposal been the law and the shrink-wrap license in ProCD not been upheld, it is hard to imagine ProCD or any other commercial entity ever compiling another directory. Intentional or not, one consequence of the Nimmer proposal would be the loss of many such economically useful, but non-copyrightable, databases.

A similar situation was presented in Warren Publishing Co. v. Microdos Data Corp.$^{20}$ There, Warren, the publisher of the Television \& Cable Factbook, sued Microdos, which had scanned the entire book and then sold a CD-ROM of the same information in competition with Warren's paper publication. The Factbook has been published every year since 1948. The portion of the Factbook involved in the litigation contained approximately 1,340 pages of data on 8,413 cable systems and their owners. A directory section provided addresses and telephone numbers for these systems, as well as viewership and programming

\footnotetext{
16. 908 F. Supp. 640 (W.D. Wis.), rev'd, 86 F.3d 1447 (7th Cir. 1996).

17. See 908 F. Supp. at 644 .

18. See 86 F.3d at 1449.

19. See 908 F. Supp. at 646.

20. 115 F.3d 1509 (11th Cir. 1997).
} 
information..$^{21}$ Warren is a sinall family-owned business. It employs a staff that each year re-surveys and re-verifies the information in the Factbook. While the Factbook is a valuable source of information (I have consulted it in my own practice), this information is collected by survey, much the way census data is collected. As the Supreme Court noted in Feist Publications, Inc. v. Rural Telephone Service Co. ${ }^{22}$ this type of survey data does not enjoy copyright protection:

[O]ne who discovers a fact is not its "maker" or "originator." The discoverer merely finds and records. Census-takers, for example, do not "create" the population figures that emerge from their efforts; in a sense, they copy these figures froin the world around them. Census data therefore do not trigger copyright because these data are not "original" in the constitutional sense. The same is true of all facts-scientific, historical, biographical, and news of the day. "[T]hey may not be copyrighted and are part of the public domain available to every person. ${ }^{23}$

Relying on Feist and its own opinion in BellSouth Advertising \& Publishing Corp. v. Donnelley Information Publishing, Inc., ${ }^{24}$ the Eleventh Circuit denied any copyright protection to the Factbook. In other words, Microdos was free under the Copyright Act to copy and sell all the information from the Warren Factbook without expending any of its own effort or cost. Needless to say, unless Warren can protect its underlying data through "non-negotiable" licenses, it has little ability to protect its tremendous yearly investment in producing the Factbook. This would be a harsh, and, one would hope, unintended consequence of the Nimmer proposal. ${ }^{25}$

Thus, the Nimmer proposal would threaten contractual protection for socially valuable products like those discussed in the cases above. And, as is clear from those cases, copyright does not currently protect these information services. Contract would seem to be the most flexible, narrowly tailored way to preserve economic incentives for providing information products, but that is precisely what would be foreclosed by the Nimmer proposal.

It might be suggested that special federal statutory protections for certain kinds of uncopyrightable information sources might be the answer to this dilemma. Draft legislation is already pending im Congress

21. See id. at 1511-12.

22. 499 U.S. 340 (1991).

23. Id. at $347-48$ (alteration in original) (emphases added) (citations omitted).

24. 999 F.2d 1436 (11th Cir. 1993).

25. Some have argued that trademark would have been a substitute cause of action for Warren. For more on the weakness of this argument, see infra note 32. 
to protect databases. ${ }^{26}$ But such sui generis protection schemes cannot obviate the need for contractual protections for two reasons. First, the scope of such legislative proposals is narrow. The database protection bill, for instance, is limited to the protection of only certain databases. The universe of uncopyrightable materials presently protected by contract is much broader, however. Examples include publishing and distribution agreements for written and film works that are uncopyrightable because the period of protection has passed or because they were improperly marked under United States law prior to 1978, and agreements protecting trade secrets and know-how. Even databases would not receive full protection, because the statutory database scheme would not eliminate the need to license those databases outside the United States. Second, as the authors themselves note, contracts normally work with, rather than in place of, federal statutory protections. Only the simplest transactions can be dealt with by statutory protection alone. Complex, interdependent licensing requires both contract and federal statutory protection.

\section{B. The Importance of Licenses That Limit "Fair Use"}

The Nimmer proposal also seeks to invalidate "non-negotiated" licenses that "abrogate or restrict the limitations on exclusive rights specified in sections 107 through 114 and sections 117 and 118 of [the Copyright Act]." But it is easy to demonstrate that there are many forms of "fair use" that need to be restricted by contract to ensure the continuing availability of the information being copied.

I begin with one of my employer's databases. The Nasdaq Stock Market, Inc., is the second largest stock market in the United States, and among the fastest growing markets in the world. Its reported daily share volume exceeds that of the New York Stock Exchange. The Nasdaq Stock Market lists about 5,983 companies' securities. ${ }^{27}$ Nasdaq also offers a forum, the OTC Bulletin Board, where broker-dealers can enter bids to buy or sell the tens of thousands of publicly traded securities that fail to meet Nasdaq's listing requirements. All in all, up-to-date quotations of brokers, dealers, and customer limit orders, as well as information on actual trades of thousands of companies' securities - all of which amount to millions of bytes of information each day-are packaged by Nasdaq into a broadcast data feed called the Level 1/Last Sale feed. ${ }^{28}$

26. See infra note 86 and accompanying text.

27. These statistics are drawn from <http://www.nasd.com/mr3a.html> (visited Sept. 17, 1998).

28. More detailed descriptions of Nasdaq, its markets, and data feeds can be found at <http://www.nasdaq.com> (visited Sept. 17, 1998). 
Not only does Nasdaq compile this data, it decides which companies will be listed on its market, and therefore included in the Nasdaq Stock Market portion of the Level 1/Last Sale feed. Nasdaq offers an extensive hearing process to issuers who do not agree with Nasdaq's decision. An affiliate of Nasdaq, NASD Regulation, Inc. (NASDR), spends millions of dollars each year educating, testing, and disciplining the brokers and dealers and their thousands of associated persons who are allowed to enter the quotes and trades reflected in the Level 1/Last Sale feed. Moreover, Nasdaq has an extensive MarketWatch system that, in real time, based on a complex series of variables, triggers alerts to a roomful of human analysts about unusual activity in the price movement or tradimg of securities that might indicate an attempt to insider trade or otherwise illegally manipulate the price of a security. These analysts can call the issuer or broker to mvestigate whether a trading halt in the security needs to be declared by the Nasdaq Stock Market. The MarketWatch department can also refer the oddity to a huge off-line Market Surveillance departnient, which disciplimes any broker or dealer found to have violated the securities laws, SEC regulations, or NASDR/Nasdaq rules and regulations.

These services come at a cost. To offer this data involves creating the market, compiling the data, verifynig the data, monitoring the market, and testing, certifying, and disciplining market participants. A large portion of these expenses are currently paid for by the revenue derived from the Level 1/Last Sale feed. Nasdaq provides its Level 1/Last Sale data to over 338,000 terminals in fifty-nine countries. ${ }^{29}$ With such a large customer base, Nasdaq can afford to charge a relatively low fee to each user for its data. Market professionals (like brokers or dealers) pay $\$ 20.00$ per month for unlimited access to real-time (less than fifteenminute delayed) data. Non-professionals are charged just $\$ 4.00$ per nonth for the same information. Professional and non-professional users who can wait fifteen minutes or more for the information receive it free of charge. ${ }^{30}$ Needless to say, Nasdaq must be able to carefully guard and restrict the use of its data im order to ensure that it can collect the millions of dollars required to fund its data collection efforts within those first fifteen minutes. Thus, the Nasdaq Subscriber Agreenient generally prohibits re-transmission of the real-tinie data. ${ }^{31}$

29. See The Nasdaq Stock Market, Inc., The Nasdaq Stock Market Fact Book \& COMPANY DiRECTORY 32 (1997).

30. See National Association of Securities Dealers, Inc., NASD Manual Rule 7010 (1998).

31. Of course, the Nasdaq agreement affirmatively grants subscribers the right "on a noncontinuous basis, [to] furnish limited amounts of the Information to customers: in written advertisements, correspondence, or other literature; or during voice telephonic conversations not 
In the Internet age, such close control of real-time data is essential. Imagine that, out of data on, say 10,000 companies, a subscriber were able, despite the restriction in the Nasdaq agreement, to retransmit on their web site the quotes and last sales of fifty companies, claiming fair use. Imagine that 200 such sites existed, each with a different set of fifty companies. In such a scenario, a vendor could simply continuously visit these 200 sites and thereby gather, in real time, the quotes and trades on all of Nasdaq's stocks, and thereafter redisseminate a complete feed without compensation to Nasdaq. Were that to happen, Nasdaq would not have the revenue feed to continue to collect, process, verify, police, and disseminate the data. ${ }^{32}$

Nasdaq does permit numerous entities to freely redisseminate its data, but it does so under a different contractual structure-a vendor agreement. ${ }^{33}$ Under this agreement, a vendor is given the authority to redisseminate data, as long as it agrees to obtain the Subscriber Agreement from its customers, and report and bill the number of customers it services to Nasdaq. In this way, Nasdaq is able to facilitate broad dissemination of its real-time data worldwide while guarding its vital revenue strean.

Despite the legitimate need to prohibit the redissemination of realtime data by unauthorized vendors of Nasdaq, the contractual scheme used by Nasdaq would be illegal under the Niminer proposal. Section (b) of the Nimmer proposal would declare unenforceable any clause that "abrogate[s] or restrict[s]" any fair use of the data, as that concept is defined under the Copyright Act. Thus, Nasdaq could not legally

entailing computerized voice, automated information mquiry systems, or similar technologies." THE Nasdaq Stock Market, Inc, Consolidated Subscriber Agreement at 1.

32. Some have argued that there are trademark causes of action that would prevent such an occurrence. They argue that a competing vendor would, in order to attract users, indicate that its data came from the compiler, such as Nasdaq. The use of the Nasdaq trademark would leave the pirating vendor open to a trademark or anti-dilution suit from the compiler. This reasoning is flawed. In the case of Nasdaq, as in the case of many databases, the competing vendor would never have to use any of Nasdaq's trademarks in order to vend its product because it would be obvious to the users where the data must have came from and that its reliability can be trusted.

It should be noted that there is a tort available to Nasdaq called "misappropriation of hot news." This cause of action was first recognized by the Supreme Court in International News Service $v$. Associated Press, 248 U.S. 215 (1918). The legislative history of the 1976 Copyright Act specifically noted that $\S 301$ was not intended to preempt this cause of action. See H.R. REP. No. 94-1476, reprinted in 1976 U.S.C.C.AN. 5659, 5748. Courts have recognized the continuing validity of the hot news tort. See National Basketball Ass'n v. Motorola, Inc., 105 F.3d 841 (2d Cir. 1997); see also Nash v. CBS, Inc., 704 F. Supp. 823, 833-35 (N.D. Ill. 1989); Mayer v. Josiah Wedgwood \& Sons, Ltd., 601 F. Supp. 1523, 1531-35 (S.D.N.Y. 1985); P.I.T.S. Films v. Laconis, 588 F. Supp. 1383, 1385-86 (E.D. Mich. 1984) (each holding all misappropriation causes of action preempted, save for International News Service). This cause of action, however, does not exist overseas and is limited to protccting the information only while it is "hot news." This protection, therefore, does not adequately protect most non-copyrightable databases.

33. See The Nasdaq Stock Market, INC, Vendor Agreement for Level $1^{\text {su }}$ Service AND LAST SALE ${ }^{\text {SM }}$ SERvice (on file with author). 
prevent the Internet recollation scheme outlined above with "nonnegotiable" contracts, despite the commercially legitimate and socially desirable need to do so.

The Nimmer proposal would permit Nasdaq to impose the restrictions on use in its current license only if the terms were "negotiable." It is not exactly clear what is meant by "negotiable" since Nimmer, Brown, and Frischling do not discuss the concept. But whatever it is intended to mean, this much must be clear: the Nimmer proposal contemplates that an attorney or another person with enough education to explain and understand the contract, as well as with enough authority to bind Nasdaq to any changes in the agreement, would be present or at least available to negotiate the terms with each customer. For customers who are now charged $\$ 4.00$ per month, or nothing if they take delayed data, Nasdaq would not have enough revenue incentive to offer this expensive and labor-intensive negotiation service to these low-end customers. Moreover, if Nasdaq is required to affirmatively "negotiate" every contract with every user, it would have to create a system for administering custom-and likely contradictory-contractual obligations among its licensees. As a result, it seems likely that dissemmation of Nasdaq real-time and delayed data would have to be restricted to the largest revenue-producing entities, for their use only. The hundreds of web sites that now dissemmate Nasdaq data would dry up. The nonprofessional and delayed services would likely disappear.

The irony is that although the Nimmer proposal is supposed to benefit sniall users and consumers, it will likely have just the opposite effect. The rule championed by the authors would force information vendors to license data only to the largest customers, for whom the cost of negotiation and administration of custom negotiated licenses could be justified by the revenue flow. Alternatively, information providers will have to raise the price of their data to the small user. This will, in turn, hurt sniall users, who are likely the niost cost-sensitive.

Nasdaq would not be a unique case. Dun and Bradstreet (D\&B) (and the other credit reporting agencies around the world) produces and distributes credit information on millions of entities. Needless to say, private and sensitive mformation about a person's financial situation legitimately needs to be guarded and prevented from redissemination. Like other information providers, D\&B uses "non-negotiable" licenses with small users to keep setup and administration costs and burdens low. Imagine that the $D \& B$ database contains 100,000 credit records. Under traditional fair use doctrine, if $D \& B$ provided five credit reports to a small user, a redissemination of those five credit reports would likely be a "fair use" of the database. Nonetheless, I would be aghast and angry if my credit report were one of the five reports that the user chose to 
post on the Internet. Today, D\&B prohibits redissemination of its reports. $D \& B$ is able to protect the privacy of the subjects of its reports by strict contractual prohibitions that undoubtedly "abrogate or restrict" fair use rights. The Nimmer proposal would declare, as a matter of law, that $\mathrm{D} \& \mathrm{~B}$ has no ability to protect privacy of credit reports where small users who obtain the information through "non-negotiable" licenses are involved. ${ }^{34}$

Similarly, D\&B is able to manage its defamation risk via contractual use restrictions. In many states, there is a qualified privilege against defamation where the information is exchanged in good faith between creditors. However, that privilege is unavailable where the data is shared with non-creditors. The D\&B license restricts not only use and redissemination of the data, but also to whom the data may be shared. Since fair use under the Copyright Act does not explicitly regulate who can receive data, the $\mathrm{D} \& \mathrm{~B}$ clause would likewise be declared unenforceable under the Nimmer proposal. The Nimmer proposal would destroy D\&B and its creditor-clients' qualified privilege. It seems safe to say that the cost of D\&B services, when fully subject to invasion of privacy and defamation claims, would be far higher than it is today. ${ }^{35}$

One more example should suffice. Most of the readers of this Comment are familiar with the WESTLAW or Lexis/Nexis limited-use services provided to law school students. WESTLAW and Lexis/Nexis are high-priced services, far beyond the means of most law students and law school libraries. Nonetheless, these (and similar information vendors) offer a "non-negotiable" educational license to students. The license permits them access to large areas of the databases, provided that the students do not'make professional or commercial use of the discounted WESTLAW or Lexis/Nexis services. While the trade-off of

34. To be sure, the Fair Credit Reporting Act, 15 U.S.C. $\S \S 1681-1681(\mathrm{e})$, provides some statutory protection for certain kinds of "consumer reports" and "investigative consumer reports" (as defined by 15 U.S.C. $\S 1681$ (a). However, like other forms of federal protection, it does not form an independent, freestanding scheme in the absence of contract. For example, most restrictions and regulations under the Fair Credit Reporting Act relate to "consumer reporting agencies," not to users or recipients of the information. See 15 U.S.C. $\$ \S 1681(\mathrm{~b}), 1681(\mathrm{~m})$ (1984). Thus, users of information who obtain the information legally under the Fair Credit Reporting Act, but then use the information for other purposes, may not be violating federal law. Moreover, the statute does not regulate credit reports of persons other than consumers. The Fair Credit Reporting Act also does not give the reporting agency a cause of action against users to prevent their unauthorized or illegal use of the data. And, as with other federal protection scheines, the Fair Credit Reporting Act does not cover unauthorized uses made outside the United States. Finally, some credit report providers (and others) fear that the Nimmer proposal, particularly as embodied in the Boucher Bill, see infra text accompanying note 86 , could be read to override or conflict with even the limited protections currently provided by the Act.

35. See generally Letter from James R. Maxeiner, Vice President and Associate General Counsel, Dun and Bradstreet, Inc., to ALI (May 19, 1997) (discussing the McManis Motion). A copy of the letter can be found at <http://www.softwareindustry.org/issues/guide/docs/jm.html> (visited Sept. 24, 1998). 
restricted use for low price seems socially beneficial, the Nimmer proposal would declare the trade-off unenforceable simce the students are making the same "fair use" of the few cases they read from the vast WESTLAW or Lexis/Nexis databases that is made by professional users, and thus leave these vendors with little choice but to withdraw the law student program. Similarly, the ProCD case involved a vendor who offered the same information to individual users at a far lower price than it offered the same information to professional users. ${ }^{36}$

The cases of harm from the Nimmer proposal for information services do not end here. Many trade secrets involve uncopyrightable information. Would the Nimmer proposal declare terms restricting use and redissemination of such trade secrets unenforceable since the information is "material that is uncopyrightable under section 102(b) [of the Copyright Act] or otherwise"? If so, how would one protect trade secrets? A license that relates to restrictions on use of a patent literally violates the Nimmer proposal simce the license terms restrict some or all of the exclusive rights of "performance," "adaptation," or "display" of an invention, and certainly patent terms prohibit what would otherwise be "fair use" under the Copyright Act. Know-how licenses would likewise have their terms routmely declared unenforceable since they too often involve uncopyrightable material. ${ }^{37}$

\section{The Unintended International Consequences of the Nimmer Proposal}

One inust also look at the effect of the Nimmer proposal on international transactions. The Nimmer proposal incorporates uniquely American notions of fair use and copyrightability into the commercial law of the United States. In international transactions involving a United States buyer, the United States could well be the contractual or default choice of law. ${ }^{38}$ Although the subject matter of the license is

36. See ProCD, Inc. v. Zeidenberg, 86 F.3d 1447, 1449 (7th Cir. 1996).

37. Even after a lengthy discussion of the importance of trade secrets and the non-preemption of trade secret protection by $\S 301$ of the Copyright Act, neither the McManis motion nor the Nimmer proposal is worded to permit protection of non-copyrightable trade secrets, nor validate restrictions on use of trade secrets that would appear to "abrogate or limit" fair use of that information. This is more than a mere oversight; any proposal that validates trade secrets would have to validate reverse engineering restrictions. One of the authors' mam hopes for their proposal is the voiding of all reverse engineering clauses. See infra Section II.D.

38. 2B-107 provides for contractual and default choices of law:

(a) The parties in their agreement may choose the applicable law. However, in a consumer transaction, the choice is not enforceable to the extent it varies a rule that cannot be varied by agreement under the law of the jurisdiction whose law would apply in the absence of the agreement.

(b) Except as otherwise provided by an enforceable choice-of-law tern, the following rules apply: 
copyrightable under the law of the producer, it may not be copyrightable under United States law (for example if the work predated the United States adoption of the Berne Treaty and was not properly marked). ${ }^{39}$ The producer today can impose contractual restrictions on the work in the United States that mirror those of the Copyright Act and do not unfairly restrict fair use of the work. However, under the Nimmer proposal, the restrictions, perfectly legal in every country but the Unites States, are declared unenforceable $a b$ initio in the United States, unless each individual license is negotiated. If the work is a inass-market work like a digital version of a sound recording or movie, the producer simply cannot afford to distribute the work in the United States since each license would have to be individually "negotiated." America is too often accused of trying to export its peculiar notions of copyright and fair use. To do so through the guise of a commercial law statute could well provoke criticism, and even retaliation, from the international community.

\section{The Unmanageable "Non-Negotiable" Standard}

A key feature of the Nimmer proposal is that it applies only to "non-negotiable" terms. The problem is that the authors do not discuss what this term means. It either means almost nothing, or it can swallow up the universe of contracting practices. ${ }^{40}$

(1) An access contract or a contract providing for electronic delivery of a copy is governed by the law of the jurisdiction in which the licenser is located when the agreement is entered into between the parties.

(2) A consumer transaction that requires delivery of a copy on a physical mediun to the consumer is governed by the law of the jurisdiction in which the copy is delivered or, in the event of nondelivery, the jurisdiction in which delivery was to have occurred.

(3) In all other cases, the contract is governed by the law of the jurisdiction with the most significant relationship to the contract.

(c) If the jurisdiction whose law governs under subsection (b) is outside the United States, the laws of that jurisdiction govern only if they provide substantially similar protections and rights to a party not located in that jurisdiction as are provided under this article. Othervise, the law of the jurisdiction in the United States which has the most significant relationship to the transaction governs.

(d) A party is located at its place of business if it has one place of business, at its chief executive office if it has more than one place of business, or at its place of incorporation or primary registration if it does not have a physical place of business. Otherwise, a party is located at its primary residence.

39. Pursuant to 17 U.S.C. $\$ 405(a)$, works created before the effective date of the Berne Convention Implementation Act of 1988 would fall into the public domain if not properly markcd with the statutorily prescribed copyright notice.

40. Perhaps the reason for the authors' silence on the issue of "non-negotiable" licenses is that none of the case law discussed in the Article supports the distinction sought to be made-a distinction that must be drawn in order to support the Boucher Bill and the McManis motion, both of which make that distinction. Numerous cases cited by the authors discuss when a law or contract is preemptcd, but none inakes preeinption dependent on whcther the contract is a standard form or was "negotiable." This flaw undermines the Article's entire analysis. 
As corporate counsel for a large corporation, I can tell you that very few terms in a contract are truly "non-negotiable." If you represent a buyer with enough economic power, with almost no exceptions, the vendor will "negotiate" the clause with you. The vendor may demand that in order to change the clause, the buyer will have to pay a far greater price, agree to other restrictions that may be difficult for the buyer to accept as a quid pro quo, or the vendor may be willing to trade concessions on this clause for concessions on another clause that the buyer desires. The fact that the buyer chooses not to accept the vendor's price for the changes requested by the buyer does not make the clause "non-negotiable." Similarly, the vendor may not agree to the changes requested by the buyer, but might be willing to offer different changes in the term or changes in related terms. In either case, the term is not "non-negotiable."

Even if you are a small user, few vendors declare terms truly "nonnegotiable." That is, out of a duty of customer service, the vendor will diligently forward the user's request to its counsel for review. Again, most often the vendor will respond with a letter proposing some mcreased price, other quid pro quo, or other restriction in order to balance the added risks to the vendor of the proposed changes. Few customers are ever willing to accept such offers, but the term is nonetheless open to negotiation.

If the term "non-negotiable" means "not typically negotiated," on the other hand, then the authors are asking that vendors (or buyers) who typically propose the terms keep an accurate track of who has asked for what changes, what the response was in each case, and what the outcome of the response was in order to show what terms are "typically negotiated." For a corporation like Microsoft or Nasdaq, a legal requirement of that kind would impose a huge paperwork burden. Moreover, I suspect, most buyers do not care to negotiate the kind of terms that concern the authors. For example, they appear to be most worried about software reverse engineering clauses, and clauses that limit the right of professors (and librarians) to use sigmificant portions of copyrighted material in classroom, distance learning, and interlibrary loan situations. While this may not be the entire universe of clauses that are the real concern of the Nimmer proposal and the McManis motion, accept for a inoment that these are among the concerns. Will the Nimmer proposal solve the problem? No. While Microsoft may sell tens of millions of copies of Windows 95, all but a handful of users would object to the anti-reverse engmeering clause in the operating systein's license. That is, the Microsoft database would likely show that there were few, perhaps twenty at inost, requests im a given year to change the reverse engineering clause. Of that, Microsoft would likely show that most 
were from users who requested reverse engineering for their internal business purposes only and were licensed the source code (under strict confidentiality), became OEMs, ${ }^{41}$ or were sold a modified object code version of the program; maybe two more were offered the right to reverse engineer in return for cross-licensing of the requester's major software patents, which the requesters declined; and two were perhaps from its major competitors who were offered the right to reverse engineer for $\$ 1$ million per year. Was the clause therefore "nonnegotiable"? Presumably, even this term was "typically negotiated," in which case the Nimmer proposal did not accomplish the result the authors intended-making reverse engineering clauses and clauses that restrict fair use illegal per se.

Parenthetically, I should note that much of the authors' confusion stems from the incorrect paradigm suggested at the beginning of the Article. The authors suggest that an Article 2 transaction "typically involves ... a negotiated contract between buyer and seller .... The typical software transaction, by contrast, does not mvolve a direct sale between the software proprietor and the end-user; rather it involves a non-negotiated license (otherwise known as a "shrinkwrap" contract) ...."42 In fact, as anyone who buys goods from a retail outlet is well aware, indirect sales involving non-negotiated contracts are very typical in Article 2 goods transactions. Similarly, as the Society of Information Managers demonstrated at a recent Article 2B Drafting Committee meeting, more than $50 \%$ of the software market involves customized software transactions with huge dollar values and extensive negotiations directly with the software provider or a developer. ${ }^{43}$

41. As defined by the Webopaedia web site, OEM

[s]tands for original equipment manufacturer, which is a misleading term for a company that has a special relationship with computer producers. OEMs buy computers in bulk and customize them for a particular application. They then sell the customized computer under their own name. The term is really a misnomer because OEMs are not the original manufacturers-they are the customizers. Another term for OEM is VAR (value-added reseller).

PC Webopaedia Definition and Links (visited November 24, 1998) <http://webopedia.internet.com/ TERM/O/OEM.html>.

42. Nimmer et al, supra note 1 , at 21 .

43. White Paper from the Society of Information Managers addressed to Carlyle C. Ring, Jr., Chair, Article 2B Drafting Committee (March 23, 1998). Page 1 of the White Paper notes:

Typically, roughly half of the software purchased by large businesses is shrinkwrap, and it is usually acquired by simply issuing a purchase order to a reseller rather than by negotiating a hicense agreement with the licensor.

Equally significant is the market for mainframe and midrange system software, which is used by business, government and institutions and is characterized by niche products at high prices (typically $\$ 100,000$ to many millions per transaction), few transactions, direct negotiation with the licensor, little or no competition, and more often than not, a mission critical application such corporate payroll, tax accounting, claims payment, or safety, health and environmental systems.

Id. (Einphasis added). 
It is not clear why the law for information and software transactions should uniquely burden the use of standard forms when the law for goods or services does not. The problenis of standard non-negotiable forms and of oppressive terms contained in them are equally present in the case of home mortgages, car sales agreements, car rental agreements, telephone service contracts, cable television contracts, airline tickets, parking lot signs that disclaim liability, and insurance policies. To clearly disadvantage one set of industries, namely, the Article $2 \mathrm{~B}$ industries, against their competitors in neighboring businesses by imposing legal restrictions on standard forms is not just.

Moreover, what the Nimmer proposal explicitly invites is state law interpretations of what is copyrightable and what is fair use under federal copyright law. This would be a disaster. Imagine a state court judge being asked whether a clause is unenforceable as a matter of state contract law, not because it violates some important public policy of his or her state, but because it merely "restricts" some federal policy articulated in a vague set of four factors, ${ }^{44}$ the application of which even the Circuits disagree, under a statute whose interpretation is otherwise exclusively delegated to the jurisdiction of federal courts. ${ }^{45}$ It is one thing to have the current situation where state courts unavoidably must decide questions like, "Is this cause of action for violation of the license one of contract (that can be litigated before me) or one of copyright law (that can only be brought in a federal court)?" It is another to advocate, as the authors do, a situation where a state statute propels state courts into the deepest, most controversial, aspects of federal copyright policy. Do the authors really want fifty jurisdictions (plus the District of Columbia and the U.S. Territories) determining what "abrogates or restricts" fair use and what is copyrightable? Or to put the question even more pointedly, do the authors want the Washington State Supreme Court deciding what is permissible reverse engineering and fair use of Microsoft's products?

44. Fair use is defined in 17 U.S.C. $\$ 107$ by a set of factors:

In determining whether the use made of a work in any particular case is a fair use the factors to be considered shall include-

(1) the purpose and character of the use, including whether such use is of a commercial nature or is for nonprofit educational purposes;

(2) the nature of the copyrighted work;

(3) the amount and substantiality of the portion used in relation to the copyrighted work as a whole; and

(4) the effect of the use upon the potential market for or value of the copyrighted work.

The fact that a work is unpublished shall not itself bar a finding of fair use if such finding is made upon consideration of all the above factors.

17 U.S.C. $\$ 107$ (1992).

45. See 28 U.S.C. $\$ 1338$ (1984) (granting exclusive jurisdiction over copyright matters to the federal courts). 
III

\section{Overreading ProCD: The Flawed Legal ANalysis UNDERL YING THE NIMMER PROPOSAL}

Not only does the authors' Article end up with a proposal that has many unintended consequences, but it relies on a flawed legal analysis to reach that result. In particular, the authors overstate the importance of the Seventh Circuit's opinion in ProCD v. Zeidenberg, authored by Judge Frank Easterbrook, and then use that case as an argunient for a major restructuring of Article $2 \mathrm{~B}$ and state contract law. But if one rejects the authors' reading of ProCD-as I do-there is no need for their solution. ${ }^{46}$

46. As I stated in note 2 supra, the first half of the Article is vastly different from the second, result-oriented half. I wish to make only a couple brief comments on the first half of the Article. First, the authors spend considerable time arguing that

[a]t least for the modes of software distribution used today, copyright law provides all the teeth a publisher needs to control use and dissemination of her work. No ersatz shark via contractual promise is necessary to enforce these rights....

[The discussion above] demonstrates that state contract law is not needed to protect the copyright interests of copyright proprietors. Those interests are safeguarded by the Copyright Act itself.

Nimmer et al, supra note 1 , at 33, 40. In other words, the authors argue that contracts are never needed to restrict the exclusive rights in software transactions. This may be true for the very simple examples the authors have chosen to use, but there are clear examples where complex use restrictions need to be spelled out im a contract, particularly where they involve bilateral and mutual obligations.

For example, 1 was involved in such a transaction with a large software producer. The Nasdaq Stock Market needed a new feature added to an existing product. The producer was not in a position to develop the feature but was willing to allow Nasdaq royalty-free access to the source code and was willing to provide some of its development personnel and resources to help Nasdaq develop the feature, provided that Nasdaq gave the developer a perpetual royalty-free license to the Nasdaqdeveloped code and the right to incorporate a version of the code into its normal product in return for a couple of years of free maintenance. Nasdaq agreed not to sell its code to any third party. Clcarly such complex interrelated and co-developed cross-licensing projects involve bilateral and mutually dependent rights, performances, and obligations. The Copyright Act simply cannot, independcnt of contract, adequately cover such situations, nor can umilateral notice of use restrictions fill the bill. Contracts, even in software transactions, are necessary.

My second comment goes to the authors' discussion of Bobbs-Merrill Co. v. Straus, 210 U.S. 339 (1908) and RCA Manufacturing Co. v. Whiteman, 114 F.2d 86 (2d Cir. 1940). Nimmer et al, supra note 1 , at $44-45$. The authors use these cases to conclude that long before ProCD "[e]arlier actors throughout the twentieth century had similarly attempted to magnify their rights through use of contract," and that such contractual restrictions, when they violate the "delicate balance" of copyright law, are invalid. See id. at 45. Bobbs-Merrill and Whiteman are not contract cases like ProCD, since both involve inere notices (Whiteman involved a notice to a subsequent buyer). As the court in Bobbs-Merrill explicitly noted, "[T]his is purely a question of statutory construction. There is no claim in this case of contract limitation, nor license agreement controlling the subsequent sales of the book." 210 U.S. at 350. Moreover, at least the Bobbs-Merrill Court was being asked to follow a series of patent cases, which at the time, permitted use restrictions on subsequent purchasers of patented goods by mere notice and without contract. The Court refused to follow the patent cases, and so refused to permit notices alone to control use, because patent law is too different from copyright law. See id. at 346 ("There are such wide differences between the right of multiplying and vending copies of a production protected by the copyright statute and the rights sccured to an inventor 
The Nimmer Article starts out with a very agreeable proposition: [B]oth at gestation and throughout its life, a copyright is owned according to a complex scheme deriving in large part from state law. ...

But it is not solely the question of ownership over which state law governs. Copyright exploitation, too, can often turn on distinctions that equally derive from state laws....

In sum, federal copyright doctrine leaves to state law the vast bulk of issues concerning contracts affecting copyright. It follows that state contract law, and cognate doctrines arising under state law, determines to a great extent the destiny of a copyrighted work and the physical object in which it is embodied. ${ }^{47}$

The authors then turn to the ProCD decision and a lengthy discussion of its preemption analysis. Needless to say, commentators have divided sharply on the reasoning in ProCD. ${ }^{48}$ Nimmer, Brown, and Frischling are certainly welcome to add their slant to those who disagree with the court's reasoning. However, criticizing Judge Easterbrook's reading of some of the cases on which he relies does not get the authors where they want to be. They want to find a way to outlaw certain kinds of clauses in "non-negotiable" settings. In order to set the stage for this, the authors are forced to claim that:

The contract at issue in ProCD, Inc. v. Zeidenberg differs from the foregoing examples im the one respect relevant to nonstatutory preemption: it contravenes one of the core policies of the Copyright Act by extending quasi-copyright protection to works that do not qualify as "original." It further fails the test of encouraging the dissemination of copyrightable works in an orderly fashion in that it seeks to bar the dissemination of uncopyrightable materials. It is, in short, nothing other than an

under the patent statutes, that the cases which relate to the one subject are not altogether controlling as to the other.") Yet the authors then turn around and argue that patent cases like Bonito Boats, Inc. v. Thunder Craft Boats, Inc., 489 U.S. 141 (1989), control the interpretation of the scope of $\S 301$ and the right of authors to charge for uncopyrightable works and for copyrighted products after the expiration of the copyright term.

47. Nimmer et al, supra note 1 , at 26.

48. In addition to the articles histed in the Nimmer Article, Nimmer et al, supra note 1, see, for example, M.A. O'Rourke, Copyright Preemption After the ProCD Case: A Market-Based Approach, 12 BeRKeley TeCH. LJ. 53 (1997) and Stephen P. Tarolli, Comment, The Future of Information Commerce Under Contemporary Contract and Copyright Principles, 46 AM. U. L. Rev. 1639 (1997). See also Note, Contract Formation and Shrink Wrap License: A Case Comment on ProCD, Inc. v. Zeidenberg, 32 New Eng. L. Rev. 513 (1998); Note, ProCD, Inc. v. Zeidenberg and Article 2B: Finally, the Validation of Shrink-Wrap Licenses, 16 J. MARSHaLL J. CoMPUTER \& INFo. L. 439 (1998); Note, Contracting Beyond Copyright: ProCD, Inc. v. Zeidenberg, 10 HaRv. J.L. \& TECH. 353 (1997); cf. Robert W. Gomulkiewicz \& Mary L. Williamson, A Brief Defense of Mass Market Sofhware License Agreements, 19 RUTGERs COMPUTER \& TECH. LJ. 335 (1996). 
attempt in effect to overrule by contract binding Supreme Court precedent.

[The authors' example] proves that absolute freedom of contract under state law relating to copyrightable works is insupportable. ${ }^{49}$

But this is to overread ProCD. The authors must accuse Judge Easterbrook of advocating a position that every contract is free of any preemption under section 301 of the Copyright $\mathrm{Act}^{50}$ in order to proceed to what is the heart of their Article-a justification for radically altering state law in order to construct a state law analogue to section 301 of the Copyright Act. That is, the authors argue that if ProCD is present law and Article $2 \mathrm{~B}$ incorporates ProCD into a statutory enactment, and any contract is thus free of any preemption from the Copyright Act, then state contract law must have a provision, namely, the Nimmer proposal, that provides the same result under state law that section 301 would have provided.

This is the fundamental error in the authors' analysis. Nowhere does Judge Easterbrook claim that contract always preempts copyright. In fact, I suspect he believes just the opposite. Take the authors' examples. If the Copyright Act requires that transfers of copyright ownership be executed in writing or that a federal definition of "children" be used, the logic of ProCD would not lead to enforcing contractual provisions contradicting those requirements. ProCD simply stands for the proposition that contractual clauses are not automatically preempted by the Copyright Act. It does not stand for the negative pregnant of that proposition, which would be that contractual clauses can never be preempted by provisions of the Copyright Act.

At the end of the ProCD opinion, Judge Easterbrook specifically addresses the issue of preemption of contractual terms by the Copyright Act. To all appearances, he states that contractual clauses can be subject to preemption by section 301 on a case-by-case basis. He begins with a lead-in discussion about whether Congress could preempt any

49. Nimmer et al, supra note 1 , at 52-53,54 (emphases added).

50. See, e.g., id. at 55 ("In Sony, the Supreme Court stated that '[copyrightl protection has never accorded the copyright owner complete control over all possible uses of his work.' Yet, in a world governed by Judge Easterbrook's radical freedom to impose terms by shrinkwrap 'contract,' there is no reason that such a conclusion should pertam. Instead, the imagination of shrinkwrap drafters can come close mdeed to aehieving the type of complete control that Sony expressiy denied them."); id. at 49 ("Judge Easterbrook's reversal of the district court's holding in ProCD citcs National Car Rental for the sweeping proposition that 'rights ereated by contract' are not 'equivalent to any of the exclusive rights within the general scope of copyright', Although that latter case did hold that the specific contract there at issue was not preempted, it did not extend its holding to contracts in general."); $i d$. at 52 ("It does not demonstrate the far greater proposition at which it [ProCD] hints: No contract relating to copyrightable goods is preempted under section 301(a).") (einphasis added). 
contractual provision that differs from the rights and obligations created by federal statute. He concludes that if Congress explicitly chooses to do so, it has that power. However, courts do not normally imply that Congress intended to prohibit private contractual clauses:

Although Congress possesses power to preempt even the enforcement of contracts about intellectual property...courts usually read preemption clauses to leave private contracts unaffected. American Airlines, Inc. v. Wolens provides a nice illustration. A federal statute preempts any state."law, rule, regulation, standard, or other provision ... relating to rates, routes, or services of any air carrier." 49 U.S.C.A. $§ 1305(a)(1)$. Does such a law preempt the law of contracts - so that, for example, an air carrier need not honor a quoted price (or a contract to reduce the price by the value of frequent flyer miles)? The Court allowed that it is possible to read the statute that broadly but thought such an interpretation would make little sense. Terms and conditions offered by contract reflect private ordering, essential to the efficient functioning of markets. Although some principles that carry the name of contract law are designed to defeat rather than implement consensual transactions, the rules that respect private choice are not preempted by a clause such as $\S 1305(\mathrm{a})(1) .^{51}$

Thus, Judge Easterbrook notes that Congress can imtend to preempt any contract that performs an "end run" around its statutory scheme of rights and obligations of a buyer and seller. But, Judge Easterbrook implicitly asks whether Congress intended the preemption clause of the Copyright $\mathrm{Act}^{52}$ to preempt all contractual terms that differed from the Copyright Act's set of rights and obligations. Judge Easterbrook finds that Congress did not intend that result:

Section 301 (a) plays a role similar to $\S 1301$ (a)(1): it prevents states from substituting their own regulatory systems for those of the national government. Just as $\S 301($ a) does not itself interfere with private transactions in intellectual property, so it does not prevent states from respecting those transactions. ${ }^{53}$

51. 86 F.3d 1447, 1454-55 (7th Cir. 1996) (citing American Airlines, Inc. v. Wolens, 513 U.S. 219 (1995)) (emphases added) (citations omitted).

52. 17 U.S.C. $\$ 301(1)$ provides:

(a) On and after January 1,1978, all legal or equitable rights that are equivalent to any of the exclusive rights within the general scope of copyright as specified by section 106 [17 U.S.C. \$ 106] in works of authorship that are fixed in a tangible medium of expression and come within the subject matter of copyright as specified by sections 102 and 103 [17 U.S.C. $\S \S 102$ and 103], whether created before or after that date and whether published or unpublished, are governed exclusively by this title [17 U.S.C. $\$ \S 101-1101]$. Thereafter, no person is entitled to any such right or equivalent right in any such work under the common law or statutes of any State.

53. 86 F.3d at 1455 (eunphasis added). 
Finally, Judge Easterbrook makes clear that he does not intend to make the reverse finding - that no contractual term is ever subject to preemption by $\S 301$ (a) of the Copyright Act:

Like the Supreme Court in Wolens, we think it prudent to refrain from adopting a rule that anything with the label "contract" is necessarily outside the preemption clause: the variations and possibilities are too numerous to foresee. National Car Rental likewise recognizes the possibility that some applications of the law of contract could interfere with the attainment of national objectives and therefore come within the domain of $\S 301$ (a). But general enforcement of shrinkwrap licenses of the kind before us does not create such interference. ${ }^{54}$

Yet the authors accuse Judge Easterbrook of making just the opposite finding. They assert that he believes in "absolute freedom of contract under state law relating to copyrightable works," 55 that in "Judge Easterbrook's radical freedom to impose terms by shrinkwrap "contract," "56 "the copyright owner [gains] complete control over all possible uses of his work," 57 and that Judge Easterbrook makes "the sweeping proposition that 'rights created by contract' are not 'equivalent to any of the exclusive rights within the general scope of copyright." "\$58 The fundamental assumption of the Article is that ProCD stands for freedom of contract unfettered by any strong public policies embodied in the Copyright Act. The authors then argue that Article 2B has adopted this same radical approach, ${ }^{59}$ and that therefore some provision needs to be added to Article $2 \mathrm{~B}$ to provide that contractual terms can be preempted by strong federal policy.

The reason why Judge Easterbrook and Article 2B do not hold radical views of contract preemption, and why Article $2 \mathrm{~B}$ does not need the Nimmer proposal (particularly given its many unintended consequences), is that courts have never needed explicit statutory permission to void contractual terms that violate public policy. Courts constantly read complementary and even conflicting pronouncements from federal and state legislatures, and from other courts and, in light of the particularized facts before them, attempt to divine what public policy requires.

54. Id. (citing American Airlines, Inc. v. Wolens, 513 U.S. 219 (1995), National Car Rental Sys., Inc. v. Computer Assoc. Int'l, Inc., 991 F.2d 426 (8th Cir. 1993)) (emphasis added).

55. Nimmer et al, supra note 1 , at 54 .

56. Id. at 55 .

57. Id.

58. Id. at 49.

59. See, e.g., id. at 23 (Article 2B makes "provisions of software licenses presumptively enforceable while providing no limitations on overreaching contract terms that proprietors may unilaterally decide to inpose."); $i d$. at 71 ("By taking no position on preemption other than that "it preempts,' the draft ratifies the status quo and makes every imaginable shrinkwrap encroachment on users' rights presumptively enforceable."). 
Consider an analogy. Article 2 of the U.C.C. governs and permits contracts of all sorts. In fact, nothing in Article 2 declares unenforceable a contract for the sale of gambling equipinent, the sale of federally prohibited drugs, or the production of a nuclear device. Article 2 does not do so and does not have to. If a contract seeks to cause a party to agree to violate federal law or a strongly held federal policy, courts have no trouble declaring that part of the contract unenforceable. No explicit statutory pronouncement, beyond the Supremacy Clause of the Constitution, which already exists and is well understood by courts, is needed. Courts are constantly reconciling and harmonizing the policies behind various laws, both state and federal. In other words, statutes are not written as if they had merger clauses. One is not expected to look only to the four corners of a particular statutory scheme for resolution of all issues related to that scheme. The beauty of the common law system is that judges are free to look at the entire body of law and find solutions and balances - within the confines of precedence and specific legislative pronounceinents - to fit the facts of the particular case before them. Judges are free to create judicial glosses and exceptions to statutory strictures. After all, the doctrine that the authors are so wedded tofair use - is an example of a judicially created exception to the explicit, seemingly contrary, pronouncements of the Copyright Act. Eventually, in 1976, Congress saw the wisdoin of the exception and decided to incorporate it permanently into the statutory scheine itself. Technology and business practices develop more quickly than the law. We should not argue that courts and parties inust be hamstrung by what will quickly become aging law. We should certainly not declare, as the Nimmer proposal does, that certain contracts are completely illegal no inatter what their social value or purpose; rather, we should permit judges to mterpret and apply law as they always have.

Often commentators see their job as criticizing a court decision and then proposing a hard and fast statutory rule to overcome what they see as a bad decision. Obviously, I do not see the ProCD decision as a bad result. Uncopyrightable materials, in my view, should not be stripped of all legal protection simply because they are not protected by the Copyright Act. The authors read the Feist decision as saying that if inaterial is not protectable by copyright or other federal law or a recogmized exception to federal law (such as trade secrets or "hot news misappropriation" ${ }^{900}$, then it cannot be protected at all. ${ }^{61}$ The authors forget

60. See supra text accompanying note 32 .

61. In fact, the authors are forced to overread Feist in much the same way they are forced to overread ProCD. The authors conclude that Feist stands for the proposition that not only does copyright law not protect unoriginal compilations of facts but also that, as a result, contract cannot protect unoriginal compilations of facts, since to permit contracts to protect such compilations would "constitute an impermissible end-run around Feist." Nimmer et al, supra note 1, at 43; see also, e.g., 
their own opening hypothesis, that contract and copyright are meant to work together to define the limits of protection. The authors and I disagree on whether protection of uncopyrightable materials by a contract is violative of a strongly held federal public policy. I do not believe it is; the authors do believe it is. As I will argue below, the authors' real remedy is to get the federal government to clarify who is right. The answer is not to change state law $\mathrm{m}$ order to resolve a debate about the proper interpretation of federal copyright law.

The authors posit a number of hypotheticals that they claim are truly unconscionable and yet permitted under their reading of ProCD, ignoring a series of escape valves built into the U.C.C. and common law that permit courts to adequately police flawed terms. Such escape valves include unconscionability, ${ }^{62}$ duress and economic duress, ${ }^{63}$ the First Amendment, antitrust law (in particular, the essential facilities doctrine) ${ }^{64}$ and unfair competition. ${ }^{65}$ Most importantly, there is the Supremacy Clause of the Constitution, which resolves any conflict between federal and state law in favor of federal law. ${ }^{66}$ I suspect that any "bizarre and oppressive" clause will violate one or more of these doctrines. Moreover, in many circumstances one can sue on an independent claim of tortious conduct, regardless of whether one is in contractual privity with the tortfeasor. ${ }^{67}$ These doctrines impose a tremendous restraint on "bizarre and oppressive" business practices.

Let us focus this approach on some of the hypotheticals raised in the Article. The hypotheticals can be divided into two classes: (1) those that violate strongly held public policies; and (2) those where small factual differences distinguish situations where the same restriction should be upheld or declared unenforceable. I start with the

id. at 46 ("As already noted, the district court concluded that a ruling in favor of [the plaintiff] would subvert Feist; indeed, there can be little doubt that plaintiff crafted its shrinkwrap with the precise goal in mind."); id. at 51 ("The shrinkwrap license at issue in ProCD undid the right of the publie that Feist conferred-the ability to copy telephone listings without liability.").

However, a fair reading of Feist can only lead to the conclusion that the Supreme Court was holding that unoriginal factual databases are unprotected by eopyright. Nowhere does the Court imply that contractual protections over these uncopyrightable databases are illegitimate.

62. Section $2 B-110$ addresses unconscionability. It is drawn from U.C.C. $\$ 2-302$.

63. A finding that a contract was formed by illegal mcans such as duress or fraud gives the aggrieved party an option to ratify or disaffirm the contract. See 1A ARTHUR L. CoRBIN, CORBIN ON CONTRACTs 538-39 (1963 \& Supp. 1994). For partieular focus in the area on restraints of trade, see 6A ARThur L Corbin, Corbin ON CONTRACTs $\$ 1405$ (1962 \& Supp. 1994).

64. There are a host of illegal activities undertaken by those with inarket power or annong persons who agree with others to unfairly restrain trade. See generally 2 EARL W. KINTNER, FEDERAL ANTITRUST LAW $\S \S 10.19-10.38$ (1980) (analyzing various theories that prohibit refusals to deal under $\S \S 1$ and 2 of the Sherman Act).

65. See generally 3 JOSEPH D. ZAMORE, BusINEsS TORTS $§ 1.03$ (1998).

66. See Ronald D. Rotunda \& John E. Nowak, Treatise on Constitutional Law 6263 (2d ed. 1992).

67. See generally ZAMORE, supra note 65 , at $\S 23.03$. 
hypotheticals violative of fundamental public policy. The preamble to the Nimmer, Brown, and Frischling Article begins with a contract by a sole source monopolist, where access can only be granted to vital information through the monopolist. Moreover, the contract apparently attempts to authorize the licenser to impose criminal sanctions without resort to a judicial forum and to conduct unannounced searches and seizures of private homes, and it prohibits printouts of the licensed texts. ${ }^{68}$ It is hard to see how a court would not strike down these provisions under any number of doctrines. First, any consent by users to acts illegal under state law would quickly be declared ineffective. The effect of consent to a criminal act, such as trespass, unlawful entry, burglary, or assault is a complex subject. However, it is clear that since crimes are a public wrong, consent from a private party obtained by duress or mistake, or where against public policy, is routinely declared ineffective. ${ }^{69}$ Second, the "essential facilities doctrine" of antitrust law would likely invalidate unreasonable access limitations. ${ }^{70}$ Further, the clauses in the authors' example appear to be unconscionable, forced under duress, and contrary to the First Amendment (and analogous state policies favoring free speech).

Similarly, the authors posit a "state law that validates all oral contracts solemnly adjured before a panel of three clergymen," including a transfer of ownership in a copyright. "Is there any doubt that, under section 301(a) of the Copyright Act, where a state law or a contractual clause violates a clearly articulated exclusive contractual limitation in the Copyright Act itself, the law or clause would be struck down? (Even the

68. Nimmer et al, supra note 1, at 20-21.

69. See generally P.H. Robinson, Criminal LAW Defenses § 66, 101(b) (1984 \& Supp. 1996) (discussing when consent is effective and ineffective in property offenses); MODEL PENAL CODE § 2.11(3) (1985) (discussing "Ineffective Consent").

70. See generally KINTNER, supra note 64 , at $\S 10.25$ (analyzing various theories that prohibit unilateral refusals to deal by a inonopolist, including Sherman Act section 2 violations); THOMAS V. Vakerics, ANTtTrust Basics \$ 5.06[5] (1997). But $c f$. Phillip AR Eeda \& Donald F. TuRner, ANTITRUST LAW $\S 736$ e(6) (1978 \& Supp. 1996) (proposing a variety of theories that could impose liability on a monopolist for a refusal to deal, but cautioning that, "[a]ll in all, we conclude that relief for arbitrary refusals to deal should be left to common law remedies or to new legislation .... State and Federal legislatures have been demonstrably able and willing to pass regulatory statutes in situations deemed important and at times to create administrative machinery to carry them out.") (citations omitted) (emphasis added). Is there any doubt that Congress would create a Federal Agency that would oversee and regulate the terms and conditions of an industry as monopolistic and overreacling as the one posited by the authors?

71. Nimmer et al, supra note 1, at 54. As the authors admit, this particular application of the hypothetical state law would be preempted by the Federal Copyright Act $\$$ 903(b). See id. ("Tlie owner of the exclusive rights in a mask work may transfer all of those rights, or license all or less than all of those rights, by any written instrument signed by sucl owner or a duly authorized agent of the owner."). There would be no reason, however, to completely invalidate the state law since it has a rational application in cases of non-exclusive licenses, and in cases that do not involve copyriglit contracts. 
authors' discussion of the hypothetical does not appear to raise a question that courts would make quick work of such clauses or laws.) Or take the case of a contractual clause that awards treble damages of attorney's fees. ${ }^{72}$ It is settled contractual policy that a contractual remedy that amounts to a penalty or punitive damage award will not be enforced. ${ }^{73}$ Article $2 \mathrm{~B}$ does not need to restate that well-settled rule of contract law for the same conclusion to result.

The authors even pose the situation where a book requires "the reader not to skip chapters, not to read any paragraphs niore than three times, not to reveal the surprise plot twists to family or acquaintances, and certainly not to quote in a book review the few paragraphs that the fair use doctrine would otherwise permit." ${ }^{\text {74 }}$ In general, a contractual term that unreasonably prohibits disclosure, criticism, or a review of a book would be struck down either as violative of the First Amendment or unconscionable under a strong state-law policy of freedom of expression. Do the authors doubt that courts will not allow themselves to be used as instruments of clauses that are so repugnant to a clearly articulated federal or state policy? Judge Easterbrook's analysis, discussed at length above, suggests that he has no such doubt, and Article $2 \mathrm{~B}$ by its silence has no such doubts. Judges do not need the Nimmer proposal to know how to do their job in such situations.

Thus, I move to the hypotheticals where small differences in the facts should make a difference in outcome. If a small change in the facts should cause the sanie clause to be declared legitimate in one case and illegitimate in another, one is encountering a situation tailor-made for a court determination of legality rather than a statutory "one-sizefits-all" solution. I argue that the authors' examples fall in the best-leftto-a-court category.

I start with the authors' examples of a shrink-wrap license on a video that states "may be viewed by no more than three people at one sitting,"75 or a clause that prohibits "private home taping" of a television program. ${ }^{76}$ While these clauses may appear absurd in the situations

72. See Nimmer et al, supra note 1 , at 56 .

73. See, e.g., RESTATEMENT (SECOND) OF CONTRACTS $\S 356 \mathrm{cmt}$. a. (1981) ("[T] he parties to a contract are not free to provide a penalty for its brcach."); 3 E.A. FARNSWORTH, ConTracts 282 (1990) ("The most important restriction is the one denying them the power to stipulate in their contract a sum of money payable as damages that is so large as to be characterized as a 'penalty'.").

74. Nimmer et al, supra note 1, at 56 (citations omitted). Forbidding the quotation of a few paragraphs in a public review can serve a legitimate need where the book is a listing of vital trade secrets.

75. Id. at 54 .

76. Id. at 55. Similarly, it might well be legitimate where the television program involved a video presentation imcorporating trade secrets, where the mformation was "top secret," or did not involve a video, but a data stream for a database that one paid little for, but was for one-time access only. 
posed by the authors, the same restrictions would appear quite reasonable: (1) where the licensed video was a presentation of top secret or trade secret information where the licensee agreed that only three named persons could view the video and no taping of the material would be permitted; (2) where the license was for a paid theater presentation of a pay-per-view prize fight and the theater owner only paid for one viewing by no more than three persons; (3) where the video was a free evaluation copy sent to a movie theater owner for its review prior to contract; or (4) where the contract was between a publisher and a team of three editors or article referees hired to review manuscripts for a publisher where the material is intended for eventual future publication and where the restriction is limited in time to pre-publication only (in which case, the publisher is seeking to protect itself against scooping of its-and its authors'-future publication by its own editors or referees).

Similarly, one could take the clause prohibiting reimportation of software in a "non-negotiable" form contract. If that form contract were between the manufacturer and its multiple distributors where exclusive geographic territories are granted to each distributor, then the clause seems quite reasonable to protect the reasonable expectations of the distributors.

The difference that a fact or two can make in analyzing the reasonableness of clauses is quite evident $\mathrm{m}$ reacting to the hypotheticals in series (i)-(v). Series (i), ${ }^{77}$ the authors claim, are all examples of clauses valid under the Copyright Act, and so I need not address thein.

Series (ii) ${ }^{78}$ involves three situations that the authors claim are clear cases of copyright misuse or antitrust violations, but the situations inay not be so clear. The first hypothetical mvolves an agreement by $\mathrm{C}$ to pay $\mathrm{G}$ a six percent royalty to permit $\mathrm{C}$ to engage in distribution of videotapes for 100 years (the same rate during and after the copyright has expired). If one imagines that the six percent royalty agreement relates solely to compensation for G's contractually inandated multimillion dollar advertising campaign of the videotapes for the entire 100year period, the clause would seem reasonable. In the second hypotheti$\mathrm{cal}, \mathrm{H}$ requires a theater owner to show and pay a single royalty rate for Gone With the Wind and Night of the Lepus. In the third hypothetical, there is an agreeinent by viewers to pay " $\$ 5$ for each 37 -minute segment"79 of Gone With the Wind and every other motion picture. This situation might be an illegal tying or might amount to copyright abuse, but would seem permissible if the royalty for the films involved a substantial volume rate discount over the royalty for Gone with the Wind

77. Id. at 64 .

78. Id.

79. Id. 
plus the royalty for Night of the Lepus and the other films when licensed alone, if there is a market at those higher rates for the individual films, and if $\mathrm{G}$ (or the viewers) has the free choice to license the films one at a time or in the package.

Imagine similar slight changes in the facts of series (iii). ${ }^{80}$ In the first situation, the theoretical agreement is for royalties related to home copying of public-domain films. The authors assert that as "such devices would render the 'limited times' provision of the Constitution a nullity, they cannot stand." where the purveyor seeks only a minimal flat amount for home taping of any work (with the rate blending the rates for copyrighted and other works) at a rate that merely compensates it for the cost of transmission and overhead. Would such an arrangement seem so outrageous? Would it be better if the law, under the Nimmer proposal, effectively prohibited any compensation from viewers for films when the copyright had expired?

The second hypothetical in series (iii) involves a license for a computer program menu structure and a "surcharge" if the menu structure is incorporated into other products. Although the authors think the law on the legality of this situation is clear, they note that when the issue came before the Supreine Court, the case below was affirmed by an equally divided court. Moreover, if the license and surcharge involved a reciprocal agreement by the licenser to consult with the licensees on proposed changes to the interface, and for support services to facilitate the interaction of these other programs and the licenser's programs, the licensing arrangement would not appear oppressive or unconstitutional.

Series (iv) ${ }^{82}$ has similarly fact-specific outcomes. The first two hypotheticals involve licenses for a still frame of a picture for an obituary and for ten seconds of a film for use in a film class. Rather than this exact factual situation, mragime that it is not a single frame of a movie, but a copyrighted and famous photograph of the actor that is under license and that the seminar is one being broadcast over network television. Such licenses are common and quite legal. Finally, the authors pose a third situation where 5000 copies of a video forbid "any and all uses in Nevada, even if such qualify as 'fair uses." "83 Imagine that this filin is a videotaped advertisement for a product that a court has already declared illegal in Nevada, and that the licensee offers a separate, nocost license for the use of parts of the advertisement by news and other public-interest orgamizations, but forbids any use that the court would

80. Id. at $64-65$.

81. Id. at 66.

82. Id. at 65 .

83. Id. 
declare to be in contempt of its mjunction against use of the film. In all these cases, are not photographers permitted to charge for use of their photographs; studios, for commercial exploitation of their works; providers, for the prevention of illegal use of their materials?

In sum, we must trust that courts will restram absurd results. To legislate against a whole class of vital contracts and to police against the possibility that one court will someday enforce one absurd contract is folly. The Nimmer proposal may well declare illegal the absurd contracts, but it also outlaws thousands of reasonable business practices.

Perhaps the best answer to the authors' fears are the words of Professor Corbin, who once stated:

Theoretically, at least, people are free to contract as they choose, limiting their rights and duties in ways that are unusual or absurd or unprofitable. Their language is subject to judicial interpretation; and in this process of interpretation the tendency away from the absurd and the unreasonable is so strong as to amount to a practical limitation upon our freedom of contract. ${ }^{84}$

The real answer for the authors, as I have noted above, is to get a clarification of, or a change in, federal law. Reading between the lines, I suspect that three issues primarily drive the Nimmer proposal. First, it bothers the authors that one can "contract around Feist." The second issue is that big software producers contractually prohibit reverse engineering of their software, which the authors believe harms the growth of competition in the software industry. Finally, the authors see the future of contracts as prohibiting even the fairest of uses. The issue of whether parties can contract around Feist or what kind of clauses violate section 107 of the Copyright Act are really federal questions and should be addressed as such.

A bill, H.R. 3048, "The Digital Era Copyright Enhancement Act," was introduced by Congressman Rick Boucher (D-Va.) in the First Session of the 105th Congress. Section 7 of that bill mirrors the Nimmer proposal:

When a work is distributed to the public subject to nonnegotiable license terıns, such terins shall not be enforceable under the common law or statutes of any state to the extent that they-

(1) limit the reproduction, adaptation, distribution, performance, or display, by means of transmission or otherwise, of material that is uncopyrightable under section 102(b) or otherwise; or

84. 3A ARThur L. Corbin, Corbin on Contracts 314 (1960 \& Supp. 1994) (emphasis added). 
(2) abrogate or restrict the limitations on exclusive rights specified in sections 107 through 114 and sections 117 and 118 of this title. ${ }^{85}$

We should await action on that bill for clarification about whether federal policy prohibits the types of clauses sought to be declared unenforceable by the Nimmer proposal.

Parenthetically, I note that Representative Boucher introduced H.R. 3048 as a substitute amendment to H.R. 2281, the WIPO Copyright Treaties Implementation Act. The Committee overwhelmingly rejected the Boucher amendment. Moreover, the House passed by voice vote first H.R. 2652, and then H.R. 2281, both containing the Collections of Information Antipiracy Act, which would explicitly provide federal protection to uncopyrightable materials ${ }^{86}$ Interestingly, section 1205 (a) of H.R. 2652 and section 1305(a) of H.R. 2281, specifically reserve a role for contract, stating that "nothing in this chapter shall affect ... the law of contract." In any event, at least the right issue is before the right body. Rather than attempting a backdoor fix to a federal problem by changes to the U.C.C., the authors should address their concerns to a federal forum.

\section{CONCLUSION}

The Copyright Act and contract law are not at war with each other, nor should we manufacture a war between the two. If contract terms, negotiated or "non-negotiable," violate strongly held federal or state public policy, courts will not uphold them. The real problem for the Article's authors is their conviction that reverse engineering and fair use restrictions fall within the category of strongly held federal or state public policy, despite their failure to persuade Congress or the federal courts to so hold. What they fail to realize is that others just as firmly believe that no such strong federal policy exists. Mr. Nimmer and his co-authors need to join the issue in federal court or in Congress and let the chips fall where they may. Harming industries through the unintended consequences of the authors' proposed amendment to Article 2B in an attempt to short-circuit the proper federal approach is not the answer.

85. The Digital Era Copyright Enhancement Act, H.R. 3048, 105th Cong. (1998).

86. See Juliana Gruenwald, House-Passed Measure Would Punish Misuses of Data Collections, 1998 Cong. Q. 1392 (May 23, 1998); Juliana Gruenwald, House Passes Protections Against Digital and On-Line Theft; Conference Faces New Issues, 1998 CoNG. Q. 2182 (Aug. 8, 1998). 